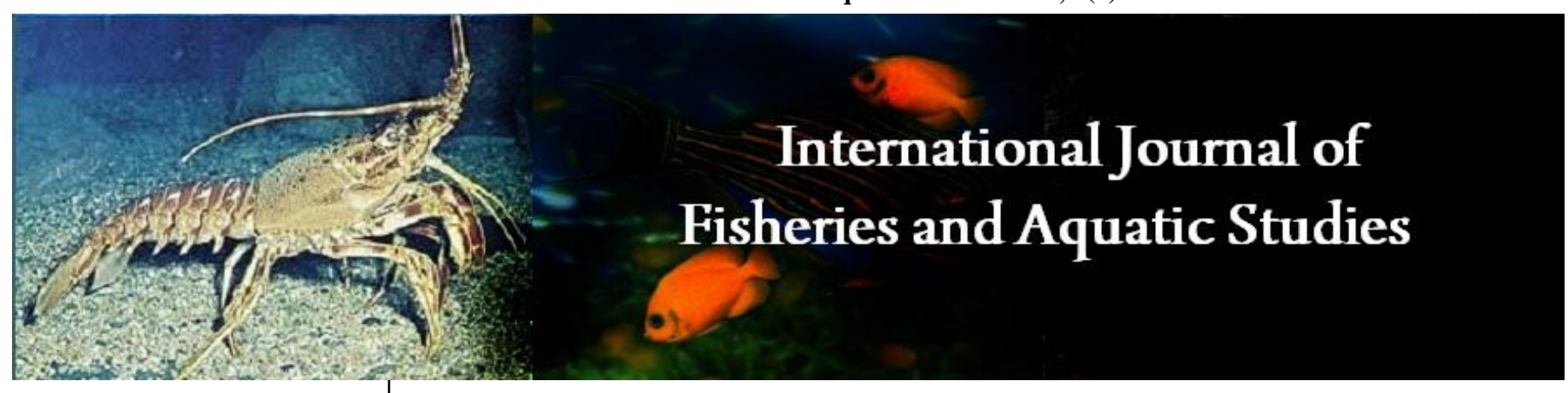

E-ISSN: 2347-5129

P-ISSN: 2394-0506

(ICV-Poland) Impact Value: 5.62

(GIF) Impact Factor: 0.549

IJFAS 2020; 8(5): 320-324

(C) 2020 IJFAS

www.fisheriesjournal.com

Received: 15-07-2020

Accepted: 19-08-2020

Aparna Roy

Scientist, ICAR-Central Inland

Fisheries research Institute,

Barrackpore, Kolkata, West

Bengal, India

Md. Aftabuddin

Principal Scientist, ICAR-

Central Inland Fisheries research

Institute, Barrackpore, Kolkata,

West Bengal, India

\section{Supriti Bayen}

Senior Research Fellow, ICAR-

Central Inland Fisheries research

Institute, Barrackpore, Kolkata,

West Bengal, India

\section{Abhishek Ghosh}

Senior Research Fellow Former,

ICAR-Central Inland Fisheries

research Institute, Barrackpore,

Kolkata, West Bengal, India

Basanta K Das

Director, ICAR-Central Inland

Fisheries research Institute,

Barrackpore, Kolkata, West

Bengal, India

Pranaya K Parida

Scientist, ICAR-Central Inland

Fisheries research Institute,

Barrackpore, Kolkata, West

Bengal, India

\section{Changing dimensions of 'Fish for All' from 'food and livelihood' to 'nutritional security'}

\author{
Aparna Roy, Md. Aftabuddin, Supriti Bayen, Abhishek Ghosh, Basanta K \\ Das and Pranaya K Parida
}

DOI: $\underline{\text { https://doi.org/10.22271/fish.2020.v8.i5d.2340 }}$

\begin{abstract}
Inland fisheries contribute more than 12.60 million metric tonnes of fish per year to food basket of India. 'Fish for all' concept was a global initiative by World Fish to improve food and livelihood security of the rural poor of the developing countries. Fish embodies more than a basis of protein source in human diet and endowed with essential micronutrients, minerals, and vitamins. It could be an essential medium to fight under-nutrition and malnutrition. Healthy population is prerequisite for sustainable growth and development of a community and a nation. Our country is facing enormous challenges to tackle the 'hidden hunger' of the young, marginal, landless working and underprivileged population. Despite, multiple nutritional intervention schemes at community level, malnutrition and under-nutrition remain a public health issue which needs to be addressed with utmost care and responsibility. Incorporation of nutrition rich Small Indigenous Fish in the daily diet of undernourished and malnourished population through different Government schemes may help our country to achieve the focus of nutritional security through accomplishing the goal of wholesome human nutrition.
\end{abstract}

Keywords: Small indigenous fish, malnutrition, nutritional security, hidden hunger

\section{Introduction}

World Fish estimated more than two billion people in the developing countries as deficient in micronutrients. In India, Rapid Survey on Children (RsoC, 2014) and National family Health Survey report (NFHS, 2006) shows that growth of $38.7 \%$ of the children are stunted and $15.1 \%$ of the children are wasted. Over the decades India has gained sizeable social and economic development, but still child and maternal malnourishment is a major concern in our country. Inadequate food and poor health are two direct factors contributing to under-nutrition and malnutrition ${ }^{[1]}$. For economic development of any country, human resource is the most important resource and children are the future seed for that resource. However, majority of the Indian rural women face nutritional deprivation since their childhood which is the major cause of malnutrition and under-nourishment of the women ${ }^{[2]}$. Considering above data and facts, undernourishment and malnutrition must be tackled with serious effort which needs policy formulation and fiscal investment in higher level vis-a-vis implementation of the schemes in local level. In this direction, 'Fish for all' concept was a global initiative (World Fish, 2002) to improve food and livelihood security of the rural poor of the developing countries. However awareness on role of micronutrients in child and women nutrition and nutritional security over food security lead the world leaders to declare 2016-2025 for Decade of Nutrition (FAO) and Decade on Action of Nutrition (UN) which changed the focus of the 'Fish for all' from food and livelihood to nutritional security with a goal to achieve wholesome human nutrition.

\section{Key components of nutritional security}

In 2009 World Summit, 'Food Security' was defined as 'when all people, at all times, have physical, social, and economic access to sufficient, safe and nutritious food that meets their dietary needs and food preferences for an active and healthy life ${ }^{[3}$. The ample availability of food, easy accessibility, proper utilization and stability of food are the three elements, often stated as the key components for food security. But, nutritional security is not just food security, it is more than that. Food security is having the economic approach, rather nutritional security is more having biological approach. For example, low income group people often

\footnotetext{
Corresponding Author: Aparna Roy

Scientist, ICAR-Central Inland Fisheries research Institute, Barrackpore, Kolkata, West Bengal, India
} 
have a tendency to take more energy-dense food with their limited income rather than costly nutrition dense food ${ }^{[4]}$. Poor people with limited income are more focused on quantity rather quality of food, whereas for aged men, pregnant and lactating women and children Nutrition means more than calories or energy. The nutritional elements (micro/macro) of food ensure healthy life and help to prevent diseases. Thereby, nutritional security can be achieved only when quality food is available in desired quantity food security or vice-versa ${ }^{[5]}$. Certain vital nutrients like minerals and vitamins have immense contribution on growth, development, immunity and reproductive health. A large numbers of ailments in human population especially women, children and aged group is the result of deficiency that can plague a community with major health affliction. In a community, assessment of nutritional status can be done by direct and indirect method [6]. Nutritional assessment requires quantity and quality of consumption and utilization of nutrients and should be interpreted with the information collected from dietary, anthropometric, clinical and biochemical studies.

\section{Potential of Fish as a nutrient rich food items for inclusion in Government Meal Scheme}

Fish is an aquatic organism rich in protein and other micronutrients which are essential for healthy body and mind. Fish provides high-quality protein, minerals and trace elements, fat-soluble vitamins and essential fatty acids, including long chain omega-3 polyunsaturated fatty acids ${ }^{[7]}$. The brackish water fishes are rich in omeg- 3 fatty acids which is also an essential element for brain development. Dietary intake of fish rich in Omega 3 fatty acid plays multiple cardio-protective roles and decrease mortality rate associated with coronary heart disease ${ }^{[8]}$. Micronutrients are essential nutrients for human nutrition and health. Though it requires in small quantities but it is essential for diverse physiological functions including growth, immunity, metabolism and reproduction. Iron present as haem in fish muscle is absorbed better by human body than the iron found in vegetable sources [9] and is essential for reducing anemia and promote growth in human. Zinc also play immense role in growth and body development. SIFs eaten as whole are good source of zinc. Fish are also rich in calcium that is an essential element to form skeleton and body. Some fish especially sea fish, shell fish etc. are rich in iodine which can be recommended for persons with iodine deficiencies. Phosphorus is a vital constituent of cell membranes and can be availed from softboned fish ${ }^{[10]}$. Vitamins are essential micronutrients help to maintain optimal health. Vitamin A is a crucial nutrient to fight night-blindness and is found in Small Indigenous Fishes like Mola (Amblypharyngodon mola) in a large quantity. Vitamin A deficiency is a solemn community health issue globally, particularly in Africa and Southeast Asia ${ }^{[1]}$. Folate, vitamins B6 and B12 are involved in protein metabolism and hemoglobin synthesis ${ }^{[12]}$. Fish and shellfish is good source of B6 and B12 and is an essential micronutrient for vulnerable human groups like children, young, aged persons as well as pregnant and lactating women.

The Small Indigenous Fish (SIFs) are rich in micro-nutrients and have great demand in the rural as well as urban markets. Even a few years ago, all these small indigenous fish were often called as 'trash fish' or 'weed fish'. But, nowadays due to nutritional values and health benefits provided to its consumers, these small fishes are termed as 'Nutri-fish'. Small Indigenous Fish like Mola (Amblypharyngodon mola), Bele(Glossogobius giuris), Darkina(Esomus danricus), Jat Punti (Puntius sophore), Tit Punti (Puntius ticto), Tengra (Mystus vittatus), Shingi (Heteropneustes fossilis), Koi(Anabas testudineus) etc. are rich in macro and micro nutrients like Iron, calcium, phosphorus, potassium, sodium, vitamin $\mathrm{A}$ and $\mathrm{D}$ etc. (Table 1) ${ }^{[13]}$. As these small fishes are eaten as a whole including bones, the availability of the minerals in the human body is better than larger fish (muscle). From olden days, fish, particularly small fish are popular in rural India for its medicinal and therapeutic values other than their source as component in daily diet. The fish may contain certain active biomolecules that proved to have these therapeutic properties. In Indian Sundarbans, Channa gachua, a snakehead murrel, is used as energy booster. It is an airbreathing freshwater fish and resides in all kind of water bodies from small ditches to rice fields in Sunderbans. The people of Sunderbans believe that consumption of Chang machh (Channa gachua) curry helps to fight anemia and boost energy of patient during convalescent period. The possible cause may be the higher level of protein content $(21.41 \pm 0.42 \%)$ and easy digestibility of the protein ${ }^{[14]}$. Therapeutic use of Channa gachua is also reported from Majuli island of Assam to treat asthma and body pain ${ }^{[15]}$. In Indian Sundarbans, lactating mothers are prescribed by the older women to eat Chela (Salmophasia bacaila) fish for more milk production. Salmophasia bacaila is rich in calcium. Generally, SIF are taken by the consumer as whole. In most of the cases the therapeutic benefit is attained by enriched mineral nutrient and bioactive components supply to consumer for providing better production ability.

Table 1: Nutrient content per $100 \mathrm{~g}$ raw edible parts of some Small Indigenous Fishes

\begin{tabular}{|c|c|c|c|c|c|c|c|c|c|c|}
\hline Species name & Protein g & Fat $\mathbf{g}$ & \begin{tabular}{|c|} 
Moisture \\
$\mathbf{g}$
\end{tabular} & Ash g & \begin{tabular}{|c|} 
Energy \\
kj
\end{tabular} & $\begin{array}{c}\text { Iron } \\
\text { mg }\end{array}$ & \begin{tabular}{|c|} 
Calcium \\
mg
\end{tabular} & $\begin{array}{c}\text { Phosphorus } \\
\text { mg }\end{array}$ & $\begin{array}{c}\text { Potassium } \\
\text { mg }\end{array}$ & \begin{tabular}{|c|} 
Sodium \\
mg
\end{tabular} \\
\hline Mola (Amblypharyngodon mola) & 17.3 & 4.5 & 75.6 & 3.5 & 445 & 5.7 & 853 & - & 152 & 39 \\
\hline Bele (Glossogobius giuris) & 16.6 & 0.4 & 80.3 & 3.1 & 292 & 2.3 & 790 & 520 & 210 & 56 \\
\hline Darkina (Esomusdanricus) & 15.5 & 3.2 & 77.1 & 4.2 & 384 & 12 & 891 & - & 200 & 110 \\
\hline Jat Punti (Puntius sophore) & 15.7 & 7.2 & 73.2 & 3.5 & 541 & 2.2 & 1042 & - & 203 & 53 \\
\hline Tit Punti (Puntius ticto) & 15.4 & 3.4 & 77.5 & 3.8 & 385 & 3.4 & 1480 & - & 187 & 61 \\
\hline Tengra (Mystus vittatus) & 15.1 & 3.4 & 77.5 & 3.8 & 428 & 4.0 & 1093 & - & 203 & 57 \\
\hline Shingi (Heteropneustes fossilis) & 19.1 & 1.9 & 79.2 & 1 & 374 & 2.2 & 60 & 220 & 300 & 54 \\
\hline Koi (Anabas testudineus) & 15.5 & 12.8 & 70.5 & 0.7 & 737 & 0.87 & 85 & 160 & 260 & 31 \\
\hline
\end{tabular}

Source: Bogard et al., 2015

Small Indigenous Fish to boost the nutritional security: Cases from India and abroad

In India, a systematic scientific study was carried out in Deltaic Sundarbans with the objective to incorporate the SIF in the daily dietary regime. Human feeding trial was conducted for thirty days in association with the ICDS centre Madanganj, Namkhana by inclusion of Small Indigenous Fishes in their daily meal for a group of 30 married women of 
age group18-35 years. Nutritional status was identified through direct and indirect method and it was found that the nutritional gap is quite prevalent in the area. About $27 \%$ women are under weight and are inclined for being morbid. The anthropometry, clinical examination, haematological and serum biochemical tests were conducted for the women before and after the feeding schedule. Feeding schedule include a total of $50 \mathrm{gm}$ Mola (Amberiphaingodon mola) and Jat Puti (Puntius sophore along with their daily diet as these two species were available in that area and having high $\mathrm{Ca}$ and protein content. After one month of feeding trial it was found that blood calcium has been improved for almost all the tested women. The occurrence of anemia has also been reduced among the women from $20 \%$ to $12 \%$ (Figure 1).

In Odisha most of the people are fish eater. But, most of the people in Odisha belong to low income group and are not able to take nutritious food daily. They generally take carbohydrate rich food. The 'fish nutrition project' has been piloted by World fish at Shriharsha Mishra Memorial Sisu Bidyalaya, a school for the deaf, blind and mentally retarded people located at Patia in Bhubaneswar. In order to ensure the intake of balanced nutritional food to the children, World Fish has introduced Anchovies fish in mid-day meal. According to the USDA National Nutrient Database, anchovies are rich in omega-3-fatty acids, protein, vitamins, and minerals like calcium, iron, magnesium, phosphorus, potassium, sodiu $\mathrm{m}$, and zinc. This fish is also a good source of vitamins such as thiamin, riboflavin, niacin, folate, vitamin C, B12, B6, A, $\mathrm{E}$, and $\mathrm{K}$. Every child of the school is given $50 \mathrm{gm}$ of small fish in one meal (Anchovy) in a week by World Fish to ascertain its acceptability among the children. The children are happy to have fish in their meal. This intervention introduced by World Fish in Odisha will be useful to improve the nutritional status of the children and will create awareness among the people regarding nutritional value of low cost brackish water fish.

In Bangladesh, it was found that 340 gm fish consumption per week by pregnant women led to improve their higher nutritional status vis-à-vis development of better newborn child as observed by multiple tests than those who consumed less fish (World Fish Fact Sheet). Sensitization programme on nutrition and trial in various parts of Bangladesh has increased the consumption of small fish among children by $23 \%{ }^{[16]}$. Fish chutney and dried fish powder made from small fish are used for fortifying food of pregnant and lactating women which are also contributing in improving the health of women and newborn babies.

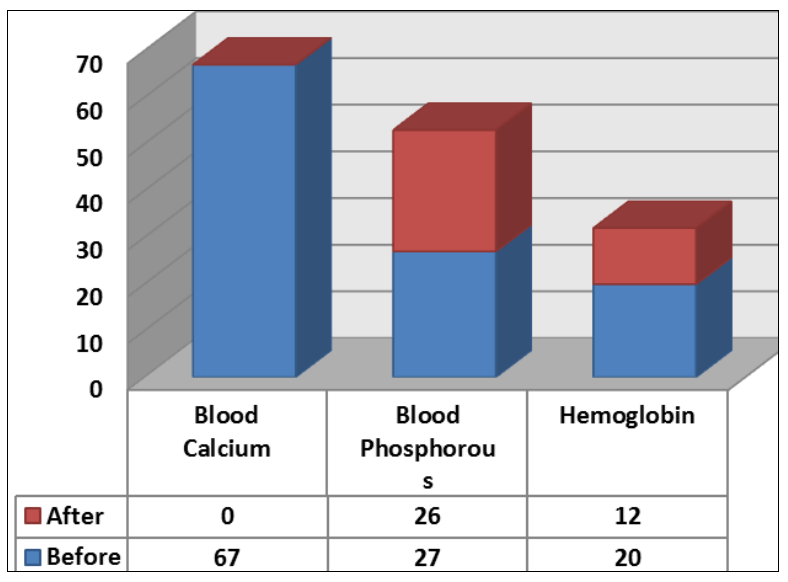

Fig 1: Effect of SIF feeding trial among the sample population in Percentage

\section{Existing policy and nutritional intervention}

Most well-known policy for fulfilling the nutritional requirement of needy population in India is led by Ministry of Women and Child Development, Ministry of Health and Family Welfare and Ministry of Human Resources Development. The schemes led by these Ministries targets the infants, school-going children and adolescent youth, pregnant and lactating mothers' for delivering nutritional supplements through Integrated Child Development Services (ICDS), MidDay Meal Schemes and Public Distribution System for fulfilling their overall nutritional requirement and finally achieving community health and well-beings(Table 2).

Table 2: Existing Nutrition Specific programmes in India

\begin{tabular}{|c|c|c|}
\hline Target group & Schemes & Interventions \\
\hline \multirow{2}{*}{$\begin{array}{l}\text { Pregnant and } \\
\text { lactating mothers }\end{array}$} & ICDS/ Anganwadi & Supplementary nutrition \\
\hline & National Rural Health Mission & Iron supplement, immunization, \\
\hline \multirow{2}{*}{$\begin{array}{l}\text { Children } \\
(0-3)\end{array}$} & ICDS/ Anganwadi & Meal to children during study period and Supplementary nutrition \\
\hline & National Rural Health Mission & Home-based new-born care, etc \\
\hline $\begin{array}{c}\text { Children (more than } \\
4 \text { years) }\end{array}$ & $\begin{array}{c}\text { Ministry of Human Resource Development: } \\
\text { Mid-Day meal schemes }\end{array}$ & $\begin{array}{l}\text { For primary level (Primary schools and Sishu Siksha Kendra): } 450 \\
\text { Calories and } 12 \text { gram of protein } \\
\text { For upper primary level (Junior School, High School and Madhyamik } \\
\text { Siksha Kendra): } 700 \text { Calories and } 20 \text { grams of protein }\end{array}$ \\
\hline
\end{tabular}

\section{Incorporation of 'Fish' as nutritional supplement in Government-aided Scheme}

Human resource is the assets of any country. Healthy population is prerequisite for sustainable growth and development of a nation. Our country is facing enormous challenges to tackle the 'hidden hunger' of the young and marginal, landless working population. Despite, multiple nutrition-based interventions at community level, malnutrition remains a public health issue which needs to be addressed with more emphasis on adopting the concept of community participation and community health. India has the highest number of world children population at the risk of poor development [17] necessitating recommendation balanced nutritious foods to satisfy their nutritional requirement.
Presently the food provided under the schemes of 'Mid-Day Meal' and Integrated Child Development Services (ICDS) are mainly based on grain with pulses, vegetables and eggs. Food preferences of population in different states of India varied with the community, food habit, culture, traditions and food items available in the region. The states having preference for fish eating in daily diet are mainly due to presence of fishproducing aquatic resources like coastal shorelines and access to huge inland fisheries resources like river, lake, wetlands and ponds. Coastal, eastern and north-eastern states have choice for fish in their daily diet. Moreover the fish production and availability are also on higher side in these states. Taking these two factors into consideration, it will be wise to incorporate the fish in the existing scheme at least on 
pilot scale. This is demonstrated with good results in our nutritional trial conducted in Sunderbans where using ICDS facility we could feed fish to women groups. However for children group we need training and awareness among the ICDS workers and guardian of the children regarding feeding of fish to infants. Fish being a source of nutritious food item, can be incorporated in the ICDS or Mid-Day Meal scheme. However, in a large country with diverse culture like India, food preference of any community is the results of climate, education, financial status, caste and availability of food to name a few. A survey by India Spend and Fact Checker revealed that $80 \%$ of Indian men and $70 \%$ of Indian women take non-vegetarian food and that fish consumption is very high in Kerala, Goa, Assam, Tripura, West Bengal, Tamil Nadu and Monipur. As India is blessed with enormous natural waters and fish diversity, low cost nutrient-rich fish can also be incorporated in the diet provided under ICDS and Mid-Day Meal schemes for visible result. In this way Small Indigenous fish laden with protein, vitamins and minerals will be able to combat the 'hidden hunger' of the underprivileged populace of the country. Although fish are nutritionally rich enough for inclusion in the daily diet to fight malnutrition and undernutrition, a few pragmatic issues may arise for incorporating it into existing policies of nutritional interventions. The issues in relation to using fish are:

- Cultural diversity and preference of the target group to fish as dietary ingredient

- Costly and perishable nature of fish in local market

- Availability of fish on regular basis

- Availability of quality and fresh fish

- Presence of bone/thorn restricting use in children and non-habitual eater

- Inclusion of fish as such may create issue relating to fish spine for infants as well as cooking may be a hindrance for its promotion

However certain steps need to be taken to overcome these issues so that promotion of the fish in daily diet of the rural poor having hidden hunger may be ensured:

- Taking into consideration of useful nutrients available in fish, Government needs to develop policy of incorporating fish in the meal of existing scheme.

- $\quad$ Fish eating population may be targeted first on pilot basis to understand the acceptability and effectiveness of the intervention. Some states like Kerala, Assam, West Bengal may be selected for introducing such intervention, as the population of these states prefers fish and availability of fish is also more.

- Low-cost trash fish (SIFs) from marine fisheries may also be introduced in the dietary regime of the target group on weekly or twice a week basis.

- Depending upon local preference and age of the target group, the fish may be processed for smooth and easy delivery, consumption and value addition. Value fish products like Fish Chatny, Achar (Pickle), Fish Chunks (like Soya Chunks) and Fish Powder may also be promoted.

- Fish powder may be promoted as cooked grain-pulsesfish powder based mixture for infants.

- Available derelict pond/water bodies may be renovated through MGNREGA scheme and may be brought under Panchayati Raj institution to produce fish under lease and supply live fish to this scheme.

- Emphasis may also be given to allot encircled area in
MGNREGA funded dug pond and wetlands to Women Self Help Group associated with Cooking of the Mid-day meal in School, ICDS centre and SSK and MSK so that SIF can be cultured and propagated. This will help in empowering both the SHG and Nutritional Intervention scheme of the government.

- Panchayet may also dug ponds in its fallow land and give lease for providing sustained fish to these units.

- Special schemes may be developed to conserve and utilize local pond for SIF culture

- Sensitization of local people to come forward for using available water resources for fish production that will make fish cheaper

\section{Conclusion}

First 1000 days of a child is very crucial for their mental and physical development. It is the unique period when the foundations are established for optimum health and development of their lifespan. Ensuring the nutrition of today's children, future mother and present mothers will also ensure the future development of India on steady shoulders. The success of any Government programme/schemes lays on approach and attitude of the implementing agencies, trained workforce, and behavior and attitude of the target group as well. We need to ensure the effective implementation of the nutritional intervention scheme to achieve our goals. Further information may be collected on loopholes of implementation, problem faced by both workers and the target group and lack of understanding and awareness of all the stakeholders. This will facilitate in strengthening our existing delivery system and make them more systematic and target group responsive to triumph over malnutrition and under-nutrition and create a healthy community for better future of the Nation.

\section{Acknowledgement}

We thank the populace of Indian Sundarban who generously share their time and information with us and also participate in the feeding trial. We are grateful to ICAR Extra Mural Fund for financial support in carrying out this work. Special thanks to Block Development Officer and Sri Bamkim C. Hazra,MLA, Sagar island Sundarban and the In-Charge, ICDSC centre, Madanganj,Namkhana for their co-operation.

\section{Reference}

1. Roy A, Manna RK, Sinha A, Das SK, Majumder S, Biswas DK et al. Conservation of Small Indigenous Fish (SIF): A roadmap to ensure food and nutritional security in coastal Sunderbans.

2. Mondal B, Sarkar D, Mukhopadhyay SD, Ghosh S, Chowdhury B, Roy SC. (Eds.), Family Farming Challenges and Opportunities, Renu Publishers, New Delhi 2016,218-228.

3. Roy A, Pandit A, Sharma AP, Bhaumik U, Majunder S, Biswas DK. Socioeconomic status and livelihood of fisher women of hooghly estuary. Journal of Inland Fisheries Society of India 2015;47(1):49-56.

4. Food and Agriculture Organization. Draft declaration of the world summit on food security. World Summit on Food Security, Rome 2009.

5. Darmon N, Elaine LF, Briend A."A cost constraint alone has adverse effects on food selection and nutrient density: an analysis of human diets by linear programming. Journal of Nutrition 2002;132:3764-3771.

6. Hwalla N, El Labban S, Bahn RA. Nutrition security is 
an integral component of food security. Frontiers in Life Science 2016;9:167-172.

7. Mahajan BK, Gupta MC. Textbook of Preventive and Social Medicine. Fourth Edition 2013, 693

8. FAO (Food and Agriculture Organization of the United Nations). FAO food and nutrition paper fats and fatty acids in human nutrition. Proceedings of an expert consultation, Geneva, Switzerland 2008;91:166.

9. McKeown D. Fish Consumption - Benefits and risks for women in childbearing years and young children. Medical Office of Health, Toronto, Canada 2006,128.

10. McManus A, Newton W. Seafood Nutrition and human health: A synopsis of the nutritional benefits of consuming seafood. Centre of Excellence Science, Seafood \& Health, Curtin Health 2011.

11. Michaelsen KF, Dewey KG, Perez-Exposito AB, Nurhasan M, Lauritzen L, Roos N. Food sources and intake of n-6 and n-3 fatty acids inlow-income countries with emphasis on infants, young children (6-24 months), and pregnant and lactating women. Maternal and Child Nutrition 2011;7:124-140.

12. Lee V, Ahmed F, Wada S, Ahmed T, Ahmed AMS, Banu $\mathrm{CP}$, Akhter N. Extent of vitamin A deficiency among rural pregnant women in Bangladesh. Public Health Nutrition 2008;12:1326-1331.

13. Bellows L, Moore R. Water soluble vitamins: B-complex and Vitamin C. Food and Nutrition Series. Fact Sheet Number 9.312. Colorado State University, U.S. Department of Agriculture and Colorado counties cooperating, Colorado, USA 2014,5.

14. Bogard JR, Thilsted SH, Marks GC, Wahab MA, Hossain MAR, Jakobsen J. Nutrient composition of important fish species in Bangladesh and potential contribution to recommend nutrient intakes. Journal of Food Composition and Analysis 2015;42:120-133.

15. Chakraborty S, Brahma BK, Goyal AK. Proximate Composition of Three Small Indigenous Fish Species Encountered in the Local Fish Market of Kokrajhar, BTAD, Assam. Indian Journal of Applied Research 2016,5(10).

16. Saikia K, Ahmed R. Wetland fish biodiversity of Majuli river island (India) and their medicinal values. The Clarion 2012,1(2).

17. Worldfish. Annual Report 2016. Penung. Malaysia 2017.

18. Niti Aayog. Nourishing India. National Nutrition Strategy. Government of India. New Delhi. India 2017. 